\title{
AC 2010-596: TEACHING AND LEARNING OF PROJECT MANAGEMENT FOR ENGINEERING AND TECHNOLOGY CAPSTONE RESEARCH PROJECTS
}

Bill Yang, Western Carolina University

Phillip Sanger, Western Carolina University

Patrick Gardner, Western Carolina University 


\title{
Teaching and Learning of Project Management for Engineering and Technology Capstone Research Projects
}

\begin{abstract}
Project management has become an increasingly important skill for engineering and technology students of the 21 st century especially for U.S. students. While much of routine design and manufacturing tasks are continuing to move overseas notably to India and China, creativity and management skills are still in high demand in the U.S. Senior capstone projects are well established as a pedagogical vehicle providing engineering and technology students the opportunity to learn and synthesize their project management skills with their other technical competences. Typically project management instruction is designed and well suited for product development and process improvement projects where the tasks can be clearly defined. It is more difficult to apply project management techniques to research oriented projects even though involving undergraduate students in leading-edge research programs often has strong and long term impact on student creativity. A typical stage- gate development process which includes stages of project definition, planning, execution, and completion, would require that existing competing products are examined and potential market discriminators for the new product clearly identified. For the research based project this stage would focus on more general applications of the technology and describing the limitations of existing technologies. At a Preliminary Design Review (PDR) gate, while a fabrication process would be identified for a product development process, methods and a plan for the research effort would be laid out. The shape of the stages and gates for new product development do not fit well and must be adapted to fit the project management needs of research oriented projects.
\end{abstract}

The paper reports on the challenge of adapting and integrating the well-developed project management principles to undergraduate research projects. By defining the product of a research project as a new piece of knowledge, and the existing market as the existing body of knowledge in a research field, we believe effective teaching and learning of project management through the undergraduate capstone research projects can be achieved and seamlessly integrated with existing product development oriented project management structures.

\section{Introduction}

$21^{\text {st }}$ century engineering and technology education in the U.S. faces unprecedented challenges ${ }^{1}$. Generation X students appear to learn differently from previous generations of students while engineering and technology pedagogy remains very similar to that of a century ago. In addition, the fundamentals and basic skills that the engineering and technology education need to cover continue to grow while the total credit hours that can be packed in a four-year curriculum are being limited. Furthermore, the biggest challenge for future U.S. engineers is the large shift in the job market with the trend of continuous shifting of routine design and manufacturing jobs to India and China. It is clear that creativity, team working, leadership, problem solving, interdisciplinary integration, and project management have become essential skills if these engineering and technology students are to remain in high-demand and be globally competitive ${ }^{1}$. These critical skills and particularly project management skills are essential for the Western Carolina University Engineering and Technology program which has adopted the project based 
learning (PBL) ${ }^{2}$ approach. PBL consists of complex tasks and challenging questions or problems that stimulate the students' problem solving, decision making, investigative skills, and reflection. PBL provides a learning environment for the students and promotes learning through investigation and research. Research suggests that the PBL learning experience tends to have a stronger long term positive influence on the students. Accordingly, real-world research questions and problems are great candidates for PBL projects. The students have to think originally and creatively to come up with the solutions to these real-world open-ended questions and problems driving students to encounter the central concepts and principles of the subject hands-on. Similar to the process where the deepest understanding of natural laws is usually achieved through excellent research, faculty research derived PBL projects can often bring about not only deeper understanding of the content but also students' life-long constructive learning and research habits. In a complementary way, project management is a discipline of planning, organizing, and managing resources to successfully complete specific project goals and objectives $^{3}$. The nominal definition of a project is a temporary endeavor undertaken to meet particular goals and objectives such as to create a unique product or service, usually to bring about beneficial change or added value. The primary challenge of project management is to successfully achieve all of the project goals and objectives within the project constraints relying on optimized allocation and integration of inputs and resources. The challenge of project management comes often in the form of nonlinear progresses typically with multiple iterations. Projects can be modeled to have some common structures such as project lifecycle as illustrated in Figure 1. Although the Fig. 1 shows a more linear progress of the project development, often the Project Planning and Design, Execution, and the Monitor \& Control interact with each other resulting in a repetitive iterative loop through these steps. While most projects share this common structure, each project will have its unique customization and adaption to fit the project goals. For example, linear progressive model works well for small, well defined projects, but often fails in larger projects of undefined and/or of ambiguous nature. On the other hand, imposing complex models for projects or tasks spanning a few weeks can be unnecessary costly time wise and inflexible, failing the project management's purpose of resources optimization.

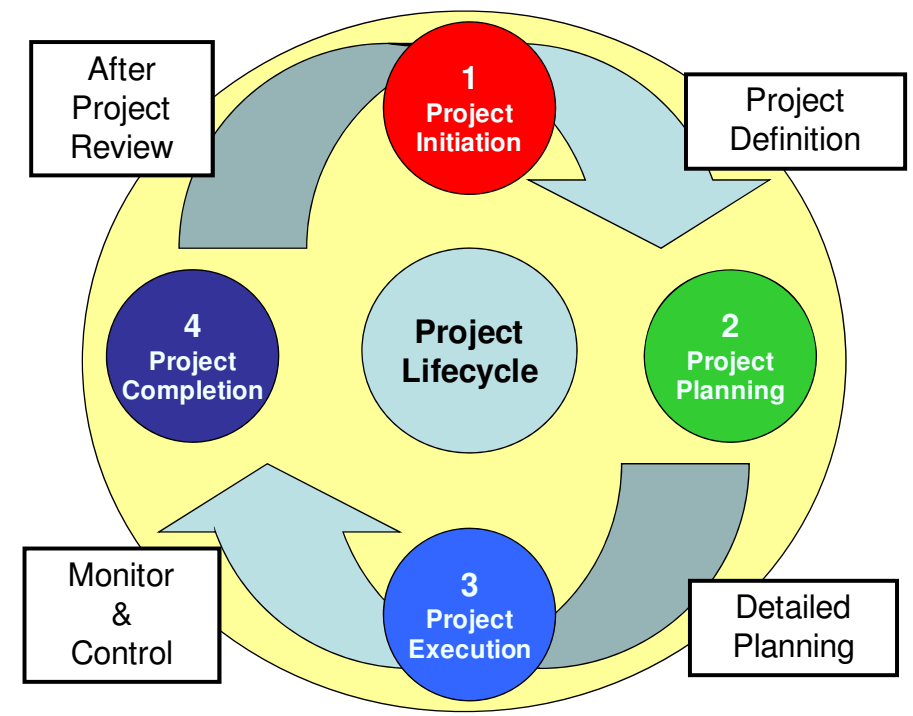

Fig. 1: Project Lifecycle. A traditional project management structure that encompasses initiation, planning, execution, and completion phases of a project. 
Some projects may not have well-defined requirements initially or the requirements can change over the course of the project. For such projects, requirements management can be essential. All these complex features of project management reflect the dynamic and complex nature of the real world. While the teaching and learning of project management in an undergraduate curriculum can only focus on the fundamentals, appreciation of these complex facets of real world project management is valuable and can be attainable through more open-ended senior capstone projects such as an undergraduate research project.

\section{A Stage-Gate Structure of Engineering and Technology Capstone Projects}

Project management should be introduced early in the student's development so that the students can apply it subsequently for all the PBL projects throughout the curriculum. When they reach the senior year capstone project, the student's project management skills should have matured and each team can optimize their project management model individually. Often however the project management content is introduced quite late in an engineering curriculum, often around the proposal phase of the senior capstone projects. At the Department of Engineering and Technology at Western Carolina University, a full two-semester two course senior capstone project sequence in the B.S. degree has been established and geared toward new product development ${ }^{4}$. One key feature in this course sequence is that the projects must be new so that it will draw the student out of their comfort zone and into the creative process.

Project management tools such as work breakdown structures (WBS), Gantt charting, scheduling and quantitative analysis of alternatives (AOA) are introduced and applied by the students in the first course in the sequence, which also spans the project proposal phase of the senior project. The course applies the Stage/Gate approach to the students' capstone project. The first and second semester are linked through this series of stages and gates. The gates, which are defined by the instructor, specify each set of deliverables and the criteria for measuring success. The sixgate structure shown illustratively in Figure 2 is currently used for the sequence and is adapted from a previous model allowing for more flexibility required by cross-concentration multidisciplinary senior capstone projects. The six gates are respectively: GATE 1 Proposal; GATE 2 Conceptual Design; GATE 3 Preliminary Design Review; GATE 4 Critical Design Review;

\begin{tabular}{|c|c|c|c|c|c|c|c|c|c|c|c|}
\hline ID & Task Name & August & Septenter & October & Novenber & Decernbe & January & Februay & Warch & April & May \\
\hline ( & & fug & Sep & oct & Noy & Dec & Jaר & Fet & Mar & App & May \\
\hline 1 & Develoc Froposal & & & & & & & & & & \\
\hline 2 & GATE 1 Proposal & & & $7^{104}$ & & & & & & & \\
\hline 3 & Develop Conceptua Design & & & & & & & & & & \\
\hline 4 & GATE 2 Conceptual Lesign & & & & $7^{115}$ & & & & & & \\
\hline 5 & Develop ApproachiDesicn & & & & & & & & & & \\
\hline 6 & GATE 3 Preliminary Lesign Review & & & & & & & & & & \\
\hline 7 & Comple:e ApproachiDes gn & & & & & & & & & & \\
\hline 8 & GATE4 Critical Design Review & & & & & & & & & & \\
\hline 9 & Execute/Build Project & & & & & & & & & & \\
\hline 10 & GATE 5 Release to Test & & & & & & & & $7^{312}$ & & \\
\hline 11 & Test System:Evaluate Results & & & & & & & & & & \\
\hline 12 & GATE 6 F nal Review & & & & & & & & & & 57 \\
\hline
\end{tabular}

Fig. 2: Gantt chart of Senior Capstone Project course sequence. 
GATE 5 Release to Test; and GATE 6 Final Review. One common constrain for all senior projects is the fixed two semester duration of the project. Figure 2 is only illustrative since it does not show the iterative process that most senior capstone projects will go through given the build-in open-ended nature of these projects. The requirement and evaluation matrix that all senior capstone projects are assessed with is shown in Table 1.

Table 1: Requirement and Evaluation Matrix

\begin{tabular}{|c|c|c|}
\hline Gates & Requirements & Rubrics \\
\hline \multirow{8}{*}{$\begin{array}{c}\text { GATE 1: } \\
\text { Project } \\
\text { Proposal }\end{array}$} & Problem Definition & $\begin{array}{l}\text { The problem is clearly stated, the background and theory } \\
\text { understood by the team. }\end{array}$ \\
\hline & Market Assessment & $\begin{array}{l}\text { Need is appraised, potential market identified, existing } \\
\text { products evaluated, stakeholder identified and roles defined. }\end{array}$ \\
\hline & Team & $\begin{array}{l}\text { Skills and commitment are adequate to be successful and } \\
\text { meet the needs of the project. }\end{array}$ \\
\hline & Design Requirements & $\begin{array}{l}\text { Measurable, specific to guide design, recognizes weakness of } \\
\text { competition or existing solutions, requirements interaction } \\
\text { understood. }\end{array}$ \\
\hline & Design Process & $\begin{array}{l}\text { WBS well thought out, logical with provisions for parallel } \\
\text { tasks, maintains options and foresees design interation } \\
\text { includes concept experimentation, customer involved. }\end{array}$ \\
\hline & Schedule and Timeline & $\begin{array}{l}\text { Aggressive but realistic, concurrent paths are used, includes } \\
\text { risk mitigation. }\end{array}$ \\
\hline & Visuals & $\begin{array}{l}\text { Relevant, reinforce message, have content, free of spelling } \\
\text { and grammatical errors, readable color selection and font } \\
\text { sizes especially }\end{array}$ \\
\hline & Delivery & $\begin{array}{l}\text { Clear enunciation and projection to audience, all the team } \\
\text { participated }\end{array}$ \\
\hline \multirow{6}{*}{$\begin{array}{l}\text { GATE 2: } \\
\text { Conceptual } \\
\text { Design }\end{array}$} & Design Requirements & $\begin{array}{l}\text { Measurable, specific to guide design, will lead to product } \\
\text { differentiation, recognizes weakness of competition. }\end{array}$ \\
\hline & $\begin{array}{c}\text { Conceptual Approaches and } \\
\text { Analysis of Alternatives (AOA) }\end{array}$ & $\begin{array}{l}\text { Adheres to requirements, three concepts developed, benefits } \\
\text { and weaknesses evaluated. }\end{array}$ \\
\hline & Development Process & $\begin{array}{l}\text { Well thought-out, logical with provisions for parallel tasks, } \\
\text { Maintains options and foresees interaction, includes } \\
\text { subcomponent testing or early investigative activities. }\end{array}$ \\
\hline & Schedule and Timeline & $\begin{array}{l}\text { Long lead items identified, aggressive but realistic, task } \\
\text { ownership clear. }\end{array}$ \\
\hline & Visuals & $\begin{array}{l}\text { Relevant, reinforce message, free of spelling and } \\
\text { grammatical errors }\end{array}$ \\
\hline & Delivery & $\begin{array}{l}\text { Clear enunciation and projection to audience, all the team } \\
\text { participated. }\end{array}$ \\
\hline \multirow{7}{*}{$\begin{array}{l}\text { GATE 3: } \\
\text { Preliminary } \\
\text { Design } \\
\text { Review } \\
\text { (PDR) }\end{array}$} & Design & $\begin{array}{l}\text { Design drawings/ models are completed, fabrication process } \\
\text { defined, theoretical approach clear. }\end{array}$ \\
\hline & Materials & $\begin{array}{l}\text { Part description completed, materials specs available, } \\
\text { software needs identified. }\end{array}$ \\
\hline & Procurement & $\begin{array}{l}\text { Budget established, suppliers identified, long lead order } \\
\text { approved and placed. }\end{array}$ \\
\hline & $\begin{array}{l}\text { Failure Modes and Effects } \\
\text { Analysis (FMEA) }\end{array}$ & $\begin{array}{l}\text { Well thought out, failure mitigation integrated in design, } \\
\text { subcomponent testing if applicable, customer involved. }\end{array}$ \\
\hline & Schedule and Timeline & Task ownership clear, progression logical. \\
\hline & Visuals & $\begin{array}{l}\text { Relevant, reinforce message, free of spelling and } \\
\text { grammatical errors }\end{array}$ \\
\hline & Delivery & Clear enunciation and projection to audience, all the team \\
\hline
\end{tabular}




\begin{tabular}{|c|c|c|}
\hline & & participated, business non-casual dress. \\
\hline \multirow{6}{*}{$\begin{array}{c}\text { GATE 4: } \\
\text { Critical } \\
\text { Design } \\
\text { Review } \\
\text { (CDR) }\end{array}$} & Design & $\begin{array}{l}\text { Meets design requirements, design drawings/models are } \\
\text { completed, fabrication process defined. }\end{array}$ \\
\hline & $\begin{array}{l}\text { Product Bill of Materials } \\
(\mathrm{BOM})\end{array}$ & $\begin{array}{l}\text { Part number and description completed, materials specs } \\
\text { available, actual costs for product identified. }\end{array}$ \\
\hline & Schedule and Timeline & $\begin{array}{l}\text { Project on schedule, updated to complete, clear task } \\
\text { responsibility. }\end{array}$ \\
\hline & $\begin{array}{l}\text { Human Subject Institutional } \\
\text { Review Board (IRB) }\end{array}$ & $\begin{array}{l}\text { Product adequately described, testing process identified, } \\
\text { feedback mechanism identified, testing population release } \\
\text { included, application submitted }\end{array}$ \\
\hline & Visuals & $\begin{array}{l}\text { Relevant reinforce message, free of spelling and grammatical } \\
\text { errors, readable and legible to the whole audience. }\end{array}$ \\
\hline & Delivery & $\begin{array}{l}\text { Clear enunciation and projection to audience, all the team } \\
\text { participated, attired appropriately, had sufficient depth, used } \\
\text { time efficiently, keep with time limits. }\end{array}$ \\
\hline \multirow{6}{*}{$\begin{array}{c}\text { GATE 5: } \\
\text { Release to } \\
\text { Test }\end{array}$} & Development/Design & $\begin{array}{l}\text { Meets design requirements, as built/implemented } \\
\text { documentation available, actual costs identified, product cost } \\
\text { updated }\end{array}$ \\
\hline & $\begin{array}{l}\text { Quality of Prototype/Research } \\
\text { Results }\end{array}$ & $\begin{array}{l}\text { Prototype/Experiment finished, and can be operated and } \\
\text { demonstrated. }\end{array}$ \\
\hline & Schedule and Timeline & Project on schedule, updated to complete. \\
\hline & Completeness of Test Plan & $\begin{array}{l}\text { Metrics of success clearly defined, testing stages and process } \\
\text { defined and goals for each stage identified. }\end{array}$ \\
\hline & Visuals & $\begin{array}{l}\text { Relevant reinforce message, free of spelling and grammatical } \\
\text { errors, readable and legible to the whole audience. }\end{array}$ \\
\hline & Delivery & $\begin{array}{l}\text { Clear enunciation and projection to audience, all the team } \\
\text { participated, Business casual attire, had sufficient depth, used } \\
\text { time efficiently, keep with time limits. }\end{array}$ \\
\hline \multirow{6}{*}{$\begin{array}{c}\text { GATE 6: } \\
\text { Final } \\
\text { Review }\end{array}$} & Requirements & $\begin{array}{l}\text { Measurable, specific to guide design, will lead to product } \\
\text { differentiation, recognizes weakness of competition updated. }\end{array}$ \\
\hline & Design & $\begin{array}{l}\text { Problems identified and addressed, design modifications } \\
\text { completed. }\end{array}$ \\
\hline & Quality of Prototype & Prototype finished, and operated and demonstrated. \\
\hline & Testing & Metrics of success demonstrated \\
\hline & Visuals & $\begin{array}{l}\text { Relevant, reinforces message, free of spelling and } \\
\text { grammatical errors, readable and legible to the whole } \\
\text { audience. }\end{array}$ \\
\hline & Delivery & $\begin{array}{l}\text { Clear enunciation and projection to audience, all the team } \\
\text { participated, Business attire, had sufficient depth, used time } \\
\text { efficiently, keep within time limits. }\end{array}$ \\
\hline
\end{tabular}

Table 1 also serves as the rubrics and evaluation matrix. For example, Gate 1 Project Proposal provides Problem Definition, Market Assessment, Team Charter, Design Requirements, Process, Schedule and Timeline. For problem definition, the problem is required to be clearly stated with the background and theory understood by the team. The market assessment needs to appraise the need, indentify the potential market, evaluate existing products, and identify all stakeholders and their roles.

A critical element of Gate 2 is the quantitative analysis of alternatives (AOA). AOA is an analytical method where alternative design approaches are evaluated and compared before committing resources to a project. It is used to establish measurable criteria for each possible solution, to formally compare all possible solutions with regard to performance, cost, feasibility 


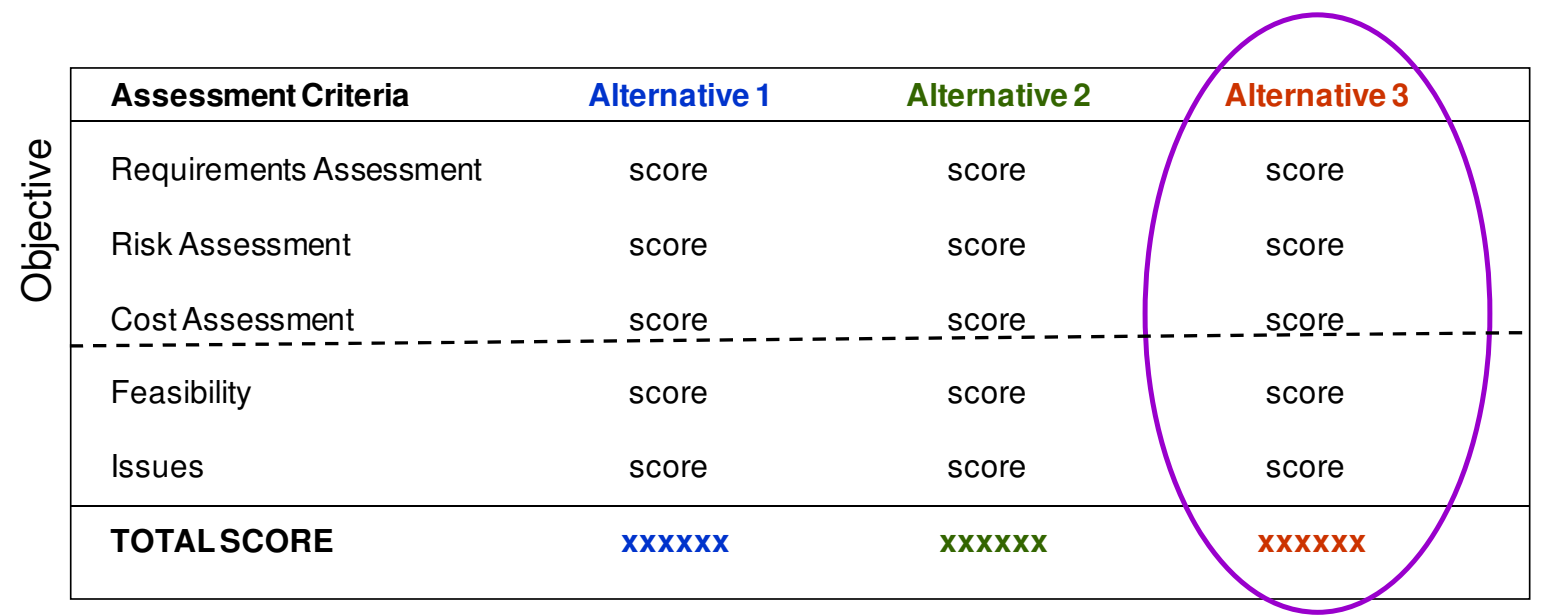

Fig. 3: Analysis of Alternatives (AOA) scorecard.

and risk, and finally, to establish a defensible basis for funding the best solution to a problem. The AOA process generates a scorecard as illustrated in Figure 3, where each possible solution is quantitatively evaluated against requirements, risks, cost, feasibility and possible issues. The alternative with the best overall "score" is selected to be the final preferred solution and further detailed risk and cost analysis is performed.

The analysis of failure modes and effects (FMEA) is a key element of Gate 3. The detailed risk analysis includes the risk assessment and mitigation that are quantified by FMEA. FMEA is a procedure for quantitative analysis of potential failure modes, effects severity, potential causes or likelihood of occurrence, probability of detection, current control methods and recommended mitigation actions. FMEA provides an analytical approach dealing with potential failure modes and their associated causes and effects. In FMEA, failures are prioritized according to how serious their consequences are, how frequently they occur and how easily they can be detected. It is a quantitative tool helping to identify which risk has the greatest concern and ensures the

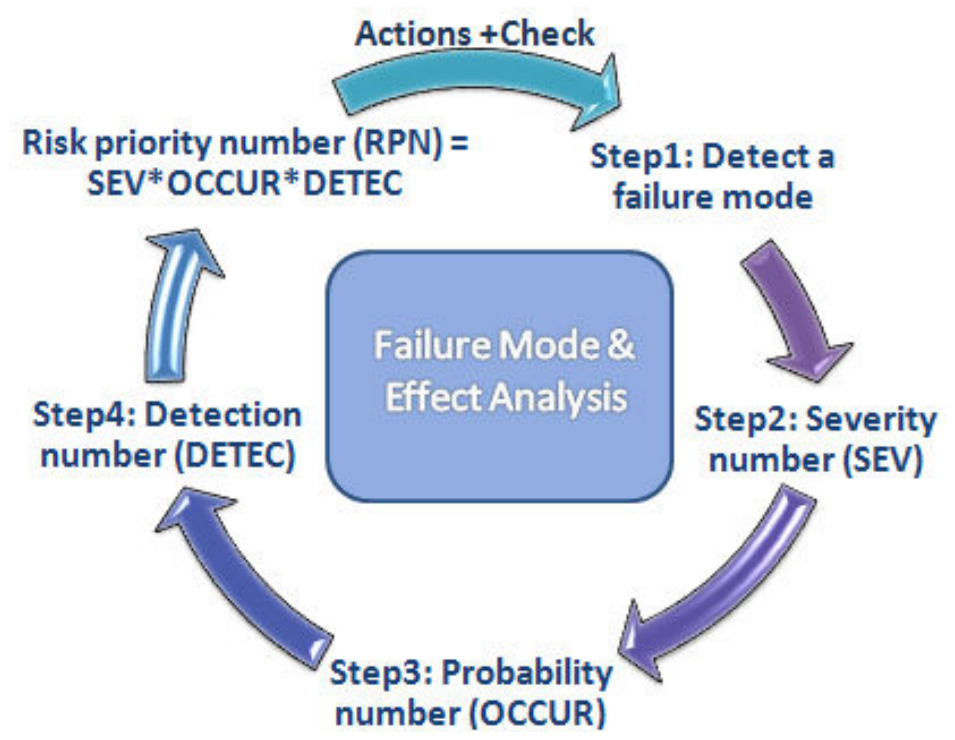

Fig. 4: Failure Modes and Effects Analysis (FMEA) model (after wikipedia article on FMEA). 
project will meet the defined requirements. A typical FMEA model is shown in Figure $4^{5}$. Finally at each gate, all student teams are required to present their projects for evaluation. The schedule and timeline are checked to ensure a well distributed effort. Visuals as well as oral delivery are required and evaluated for each member of the teams. Project documentation including requirement matrix, market analysis, AOA, FMEA, and the actual design files and test results are maintained by each project team. Over the past three years sixty students have followed the senior capstone course sequence and six patentable products have been created. In the current class, about fifty students from all three concentrations: Engineering Technology (ET), Electrical Computer Engineering Technology (ECET), and Electrical Engineering (EE) are participating in total of 15 sponsored projects. The projects range from new product development in radio therapy to fundamental metamaterial research. The improved flexibility of the gate structure allows for such cross-concentration multi-disciplinary teams and projects.

\section{The Example of Senior Research Capstone Projects}

As can be seen from the previous section, the current gate structure for teaching and learning project management in a two semester, two course senior capstone project sequence is well crafted. This well-structured course sequence and project management model is well suited to new product development projects and has resulted in satisfactory outcomes. The structure also provides a unified course management and assessment process that is applied to all senior students from all programs in the department. Students usually only encounter serious undergraduate research projects in their senior year and in the senior capstone projects. One of the goals of the senior capstone project is to create an opportunity for innovation and gain confidence in solving open-ended problems ${ }^{4}$. Undergraduate research projects fit greatly for the purpose. At Western Carolina University, we have an active research program in slow/fast light and metamaterials. This research program in collaboration with University of North Carolina Charlotte has generated valuable contributions to the research community. The current undergraduate research team consists of two electrical engineering seniors who are investigating the time-domain effects of the slow/fast light effects in metamaterial structures. This project builds on the previous effort of frequency-domain investigations that confirmed tunable group delay from negative values to large positive values in a metamaterial structure based on large form-birefringency ${ }^{6}$.

Metamaterials in general refer to artificially engineered electromagnetic materials that possess unusual properties not readily available in nature. Normally all media exhibit a positive index of refraction. A positive index of refraction ensures that when electromagnetic waves strike the medium from air, the incident beam and the refracted beam are on the opposite sides of the normal to the interface. Veselago first postulated in 1960s that negative index of refraction can exist. A negative index of refraction will result in a refraction, where the incident beam and the refracted beam will be on the same side of the normal. In 2000 Sir Pendry further postulated that a slab of negative index materials (NIM) is capable of perfect imaging ${ }^{7}$. Pendry's theoretical result which still remains controversial has inspired exponential growth in research activities in NIM and in metamaterials. Metamaterials offer the potential for many unprecedented applications including super-resolution imaging, quantum levitation, optical black hole, and invisibility cloak. 
Our research program is investigating slow and fast light phenomena in form-birefringent metamaterial structures. Mandatori et. al. first predicated in theory that a layered structure with anisotropic layers can exhibit an anomalous phase that gives rise to negative group velocity and effective negative index of refraction ${ }^{8}$. The simplest Mandatori structure involves a single layer of birefringent material and can be reduced to a birefringent filter model where a piece of anisotropic medium is sandwiched between two parallel polarizers as shown in Figure 5. The realization that this familiar structure can provide a negative group delay and therefore effective negative index of refraction is a little surprising. Naturally occurring birefringent media usually suffer a low index contrast $\Delta \mathrm{n} / \mathrm{n}$, which renders the predicted anomalous phase behavior barely noticeable or useful. By using form-birefringent metamaterial structures, we have achieved very large birefringence making compact Mandatori structures viable. These novel structures have important applications in optical data processing as well as provide challenges to fundamental understandings of nature. For example, in fast light structures, the group velocity of electromagnetic waves can be negative representing a transmission of light pulse peaks at a speed that is faster than the speed of light in vacuum which according to Einstein is the limit of any movement or information transmission. Previous frequency-domain experiments have confirmed the controllable negative group index as large as $n_{g}=-1.1$ and extremely slow light phenomena with positive $n_{\mathrm{g}}$ as large as 30 . The current research challenge is to understand what these unusual electromagnetic propagation properties really mean. For example, if we launch an electromagnetic pulse in the frequency band where the group index is negative, will the pulse

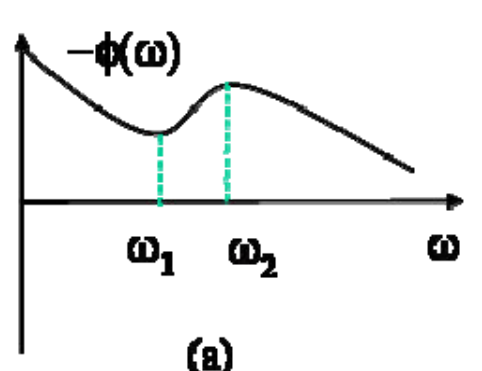

(a)

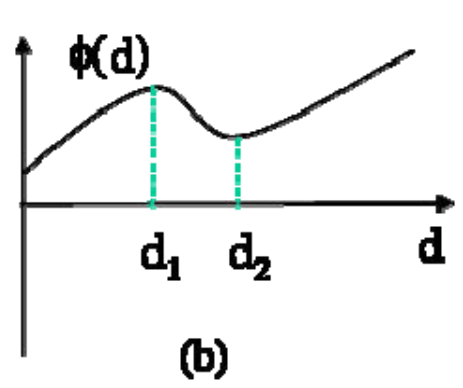

(b)
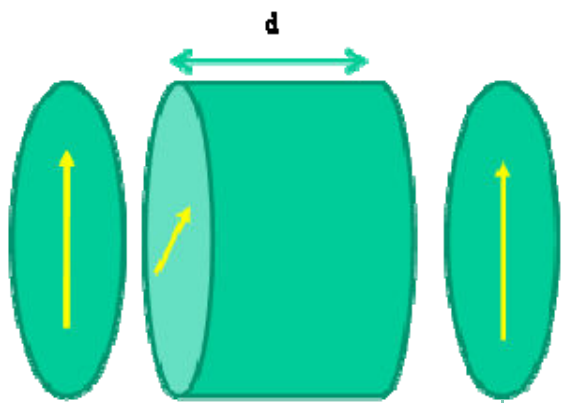

Fig. 5: Single-layer Mandatori structure (Right) that exhibit negative group index in a frequency band (a), which is also equivalent to a negative index of refraction within a range of thickness (b).

come out the fast light structure even before it enters in it as implied by the negative group delay predicated by Fourier transform principles? Can we apply this fast light scheme to transmit information encoded by the electromagnetic pulses faster than the speed limit Einstein has argued so profoundly from the causality principles? These are intriguing fundamental questions that we can experimentally explore in an easily controlled fashion using a tunable metamaterial. This project presents an interesting research opportunity to undergraduates as well as having significant scientific value.

\section{Integration of Undergraduate Research Capstone Projects}

While the research project outlined in the previous section is suitable for an EE senior capstone research project, the gate structure for the senior capstone project discussed earlier which was 
developed for product development projects must be modified to fit this type of research projects. The challenge is therefore how to seamlessly integrate these well-developed project management tools with the equally beneficial undergraduate research projects. In addition, project management for research projects is in fact itself a challenge for most researchers. Part of the problem here is that most researchers have not been subject to the rigorous project management training as we try to teach and practice here. Nonetheless, the project management skills become more and more important for researchers and research projects. Virtually every research grant proposal now requires a well-thought out project plan including deliverables, schedules and timelines, milestones and budget. The students will benefit immensely through the practice of applying a rigorous project management model to their research projects.

Our effort to integrate the well-developed structures and tools of project management for product development with the undergraduate capstone research projects starts by defining the product of a research project as a new piece of knowledge. Accordingly, the market is the existing body of knowledge in a research field. Following this basic concept, most of the project management structures and tools for product development can be mapped seamlessly to research projects. Take the previous outlined senior capstone research project for slow/fast light as an example, the student team has followed the gate structure discussed previously smoothly with the help of the faculty mentor and research sponsor. The synopsis and problem statement of the project reads:

Metamaterials are man-made materials used to enhance the capabilities of certain products to be greater than that of natural materials. In recent experiments, it has been shown that by using meta-materials, one can observe a negative group delay theoretically and experimentally in the frequency domain. By using the inverse Fourier transform of the results, it can be shown, theoretically, that the negative group delay can be observed in the time domain. This implies that by applying a frequency pulse you can see the output pulse before the input pulse enters the media. This draws the conclusion that the pulse is propagating through the media at a speed faster than the speed of light. Our objective is to prove if this theory is physically possible through experimentation.

Accordingly, Table 2 below shows the requirement matrix of the project.

Table 2: Requirement Matrix for Slow/Fast Light Project

\begin{tabular}{|c|c|c|c|c|c|c|}
\hline $\begin{array}{c}\text { Req. } \\
\#\end{array}$ & Brief Description & Threshold & Objective & Stated & Derived & $\begin{array}{c}\text { Affected } \\
\text { Requirements }\end{array}$ \\
\hline 1 & $\begin{array}{l}\text { Research \& report } \\
\text { background information(in } \\
\text { advance of experiments) }\end{array}$ & $\mathrm{X}$ & & $\mathrm{X}$ & & \\
\hline 2 & $\begin{array}{l}\text { Verify time domain } \\
\text { hypothesis at } 10 \mathrm{GHz}\end{array}$ & $\mathrm{X}$ & & $\mathrm{X}$ & & 1 \\
\hline 3 & $\begin{array}{l}\text { Analyze \& Report } \\
\text { deficiencies in math if } \\
\text { hypothesis fails }\end{array}$ & & $X$ & $\mathrm{X}$ & & $1,2,4,5$ \\
\hline 4 & $\begin{array}{l}\text { Maintain bandwidth but } \\
\text { increase negative group } \\
\text { delay by } 100 \%\end{array}$ & & $\bar{X}$ & $\bar{X}$ & & 3 \\
\hline
\end{tabular}




\begin{tabular}{|c|l|c|c|c|c|c|}
\hline 5 & $\begin{array}{l}\text { Maintain negative group } \\
\text { delay but increase } \\
\text { bandwidth by 50\% }\end{array}$ & $\mathrm{X}$ & $\mathrm{X}$ & 3 \\
\hline 6 & $\begin{array}{l}\text { Publish results (at least one } \\
\text { paper) }\end{array}$ & $\mathrm{X}$ & $\mathrm{X}$ & & $1,2,3,4,5$ \\
\hline
\end{tabular}

Project management tools such as WBS, Schedule, and BOM are more straightforward to be applied to research projects. For Gate 2 Conceptual Design and AOA, however, the students are required to investigate alternative approaches that can potentially deliver the desired research results, i.e., testing the hypothesis and investigate the possible explanations and conclusions. These equally useful project management tools such as AOA and FMEA are less intuitive for research projects. The exercise is however a valuable experience and the process is useful in determining the best approach to a research problem. Accordingly, Table 3 and Table 4 below outline the detailed conceptual approaches and quantitative AOA.

Table 3: Conceptual Approaches

\begin{tabular}{|l|c|c|c|}
\hline & Experimental Approach & Theoretical Approach & Numerical Simulation \\
\hline Concrete Evidence & Yes & Yes & Yes \\
\hline Do in time domain & Yes & Yes & Yes \\
\hline Do analysis in 10GHz range & Yes & Yes & Yes \\
\hline Observe Negative Group delay & Yes & Yes & Yes \\
\hline Tests hypothesis & Yes & Yes & Yes \\
\hline Customer Preference & Yes & No & No \\
\hline
\end{tabular}

Table 4: Quantitative AOA score card

\begin{tabular}{|c|c|c|c|c|}
\hline "Criteria" & Weight & $\begin{array}{c}\text { Experimental } \\
\text { Approach }\end{array}$ & $\begin{array}{c}\text { Theoretical } \\
\text { Approach }\end{array}$ & $\begin{array}{c}\text { Numerical } \\
\text { Simulation }\end{array}$ \\
\hline $\begin{array}{c}\text { Difficulty of Method } \\
\text { Level of Knowledge } \\
\text { Required }\end{array}$ & 0.15 & 6 & 9 & 7 \\
\hline $\begin{array}{c}\text { Instrument Interface } \\
\text { Concrete Evidence }\end{array}$ & 0.05 & 6 & 9 & 8 \\
\hline Cost & 0.05 & 5 & 1 & 6 \\
\hline Time & 0.1 & 9 & 1 & 7 \\
\hline Customer Preference & 0.25 & 7 & 7 & 5 \\
\hline Utility Score & & 10 & 5 & 5 \\
\hline $\begin{array}{c}\text { Difficulty of Method } \\
\text { Level of Knowledge } \\
\text { Required }\end{array}$ & & 1 & 0 & 0.67 \\
\hline $\begin{array}{c}\text { Instrument Interface } \\
\text { Concrete Evidence }\end{array}$ & & 1 & 1 & 0.33 \\
\hline
\end{tabular}




\begin{tabular}{|c|c|c|c|c|}
\hline Cost & & 0 & 1 & 0.43 \\
\hline Time & & 1 & 0 & 0 \\
\hline Customer Preference & & 1 & 0 & 0.1 \\
\hline Weighted Score & & & 0 & 0.05 \\
\hline $\begin{array}{c}\text { Difficulty of Method } \\
\text { Level of Knowledge } \\
\text { Required }\end{array}$ & & 0.15 & 0.05 & 0 \\
\hline $\begin{array}{c}\text { Instrument Interface } \\
\text { Concrete Evidence }\end{array}$ & & 0.15 & 0 & 0 \\
\hline Cost & & 0.25 & 0.05 & 0.02 \\
\hline Time & & 0.1 & 0.1 & 0.1 \\
\hline $\begin{array}{c}\text { Customer Preference } \\
\text { TOTAL }\end{array}$ & & 0.25 & 0 & 0 \\
\hline
\end{tabular}

As clearly presented in above score card, the experimental approach is the choice for the preferred approach. Similarly, for satisfy a Gate 3 requirement, the FMEA is performed and summarized in Table 5.

Table 5: FMEA

\begin{tabular}{|c|c|c|c|c|c|c|c|c|c|}
\hline Step/Part & \begin{tabular}{|c|} 
Potential \\
Failure \\
Mode \\
\end{tabular} & \begin{tabular}{|c|} 
Potential \\
Failure Effects
\end{tabular} & SEV & Potential Causes & $\mathrm{OCC}$ & $\begin{array}{l}\text { Current } \\
\text { Controls }\end{array}$ & DET & RPN & $\begin{array}{c}\text { Actions } \\
\text { Recommended }\end{array}$ \\
\hline $\begin{array}{c}\text { Measurements/ } \\
\text { technique }\end{array}$ & $\begin{array}{l}\text { Incorrect } \\
\text { results }\end{array}$ & $\begin{array}{c}\text { Not achieving } \\
\text { desired } \\
\text { results/conclusion }\end{array}$ & 8 & $\begin{array}{c}\text { Not correct } \\
\text { measurement or } \\
\text { correct testing }\end{array}$ & 3 & \begin{tabular}{|} 
Be sure your \\
following \\
the correct \\
steps needed \\
to do the test
\end{tabular} & 7 & 168 & $\begin{array}{c}\text { Follow steps } \\
\text { carefully }\end{array}$ \\
\hline Instru & $\begin{array}{c}\text { Bad } \\
\text { calibration } \\
\end{array}$ & $\begin{array}{c}\text { Affects the testing } \\
\text { results }\end{array}$ & 8 & $\begin{array}{c}\text { ESD, didn't use } \\
\text { instrument correctly }\end{array}$ & 5 & $\begin{array}{l}\text { Properly } \\
\text { follow the } \\
\text { procedure }\end{array}$ & 3 & 120 & $\begin{array}{l}\text { Wear ESD } \\
\text { bracelet, Don't } \\
\text { skip steps in the } \\
\text { procedure }\end{array}$ \\
\hline $\begin{array}{c}\text { Quality of } \\
\text { Metamaterials }\end{array}$ & $\begin{array}{c}\text { Produce } \\
\text { unreliable } \\
\text { results } \\
\end{array}$ & $\begin{array}{c}\text { Not achieving } \\
\text { desired } \\
\text { results/conclusion }\end{array}$ & 9 & \begin{tabular}{|c} 
Incorrect \\
fabrication/incorrect \\
design
\end{tabular} & 3 & $\begin{array}{c}\text { Double } \\
\text { check } \\
\text { quality } \\
\text { assurance }\end{array}$ & 3 & 81 & $\begin{array}{l}\text { Visually inspect } \\
\text { meta-material }\end{array}$ \\
\hline Parasitic & $\begin{array}{c}\text { Multiple } \\
\text { Reflections } \\
\end{array}$ & $\begin{array}{l}\text { Affects the } \\
\text { accuracy of the } \\
\text { testing results }\end{array}$ & 7 & $\begin{array}{c}\text { Extra materials laying } \\
\text { around testing area }\end{array}$ & 4 & Clean up & 1 & 28 & $\begin{array}{c}\text { Double check to } \\
\text { make sure area is } \\
\text { clean }\end{array}$ \\
\hline $\begin{array}{c}\text { Insufficient } \\
\text { documentation } \\
\text { on previous } \\
\text { experimentation }\end{array}$ & $\begin{array}{l}\text { Unable to } \\
\text { confirm the } \\
\text { previous } \\
\text { experiment }\end{array}$ & \begin{tabular}{|} 
Not achieving \\
desired \\
results/conclusion
\end{tabular} & 9 & \begin{tabular}{|c|} 
Previous data \\
incorrect/experiment \\
done \\
incorrectly/structure \\
degradation \\
\end{tabular} & 2 & \begin{tabular}{|c|} 
Verify \\
experiment \\
was \\
conducted \\
correctly \\
initially \\
\end{tabular} & 1 & 18 & $\begin{array}{c}\text { Read through } \\
\text { documentation } \\
\text { thoroughly and } \\
\text { ask for help from } \\
\text { advisor }\end{array}$ \\
\hline
\end{tabular}


Again, the FMEA is also a useful exercise where the most possible failure modes are readily and correctly identified. This can be extremely important in the project execution phase where special attentions are needed to target at and mitigate these risks.

\section{Conclusions and Outlook}

In the process of meeting gate requirements, it has been observed that the student team, compared to previous less rigorously managed research project teams, obviously spent much more time and effort in project planning and exercises on various project management tools such as quantitative AOA and FMEA. This inevitably left less time for the team to spend on background literature research and actual experimental studies of the subject, partly because all senior projects deliver the gate presentations at the same dates. As mentioned before, ideally the project management tools should be introduced early on in a PBL curriculum and at the senior capstone project level the teams can optimize their own project management model and timeline individually. Our main effort here in this paper is to establish the ground work and set an example for future undergraduate senior research projects to incorporate more rigorous project management tools and contents. We have found that by defining the product of a research project as a new piece of knowledge, and the market as the existing body of knowledge in a research field, the effective teaching and learning of project management through the undergraduate capstone research projects can be achieved and seamlessly integrated with product development oriented project management structures. The process also provides the students a valuable exposure and experience to project management tools and concepts adapted to research projects. With the flexibility and adaptation we demonstrated here for the gated project management structure, the students will have more opportunities and be able to apply it to various projects throughout the whole curriculum including the senior capstone research project.

\section{Bibliography}

1. P. D. Galloway, The 21st-Century Engineer: A Proposal for Engineering Education Reform, ASCE (2008).

2. B. Barron, "Doing with understanding: Lessons from research on problem- and project-based learning." Journal of the Learning Sciences. v.7, pp.271-311 (1998).

3. J. R. Meredith and S. J. Mantel Jr., Project Management: A Managerial Approach, Sixth Edition. Wiley (2003). 4. P. Sanger, C. Ferguson, and W. Stone, "Integrating Project Management, Product Development and Senior Capstone into a Course Sequence that Creates New Products and Patents for Students." ASEE Annual Conference, paper AC2009-888 (2009).

5. "Failure Mode and Effect Analysis," Wikipedia on-line article, http://en.wikipedia.org/wiki/Failure_mode_and_effects_analysis.

6. K. Sinchuk, et. al., "Tunable negative group index in metamaterial structures with large form birefringence," Optics Express, v.18, pp.463-472 (2010).

7. J. B. Pendry, "Negative refraction makes a perfect lens," Phys. Rev. Lett., v. 85, pp. 3966-3969 (2000).

8. A. Mandatori, C. Sibilia, M. Bertolotti, S. Zhukovsky, J. W. Haus, and M. Scalora, "Anomalous phase in onedimensional, multilayer, periodic structures with birefringent materials," Phys. Rev. B 70, 165107 (2004) 